\title{
Sudden Death of Citrus in Brazil: A Graft-Transmissible Bud Union Disease
}

M. P. Román, M. Cambra, J. Juárez, P. Moreno, and N. Duran-Vila, Departamento de Protección Vegetal y Biotecnología, Instituto Valenciano de Investigationes Agrarias, Carretera de Moncada a Náquera km 4.5, 46113-Moncada, Valencia, Spain; F. A. O. Tanaka, E. Alves, and E. W. Kitajima, NAP/MEPA, Escola Superior de Agricultura "Luiz de Queiroz", Universidade de São Paulo, Av. Pádua Dias, 11, CEP 13418-900, Piracicaba, SP, Brazil; P. T. Yamamoto, R. B. Bassanezi, D. C. Teixeira, W. C. Jesus Junior, A. J. Ayres, and N. Gimenes-Fernandes, Fundecitrus, Av. Dr. Adhemar Pereira de Barros, 201, CEP 14807-040, Araraquara, SP, Brazil; F. Rabenstein, Federal Centre for Breeding Research on Cultivated Plants, Institute of Resistance Research and Pathogen Diagnostics, P.O. Box 1505, D-06435 Aschersleben, Germany; L. F. Girotto, Sucocítrico Cutrale S/A, via de acesso Eng. Ivo Najm, 3800, CEP 14807-900, Araraquara, SP, Brazil; and J. M. Bové, Institut Nationale de la Recherche Agronomique and Université de Bordeaux 2, IBVM, Laboratoire de Biologie cellulaire et moléculaire, BP 81, 33883 Villenave d'Ornon cedex, France

\begin{abstract}
Román, M. P., Cambra, M., Juárez, J., Moreno, P., Duran-Vila, N., Tanaka, F. A. O., Alves, E., Kitajima, E. W., Yamamoto, P. T., Bassanezi, R. B., Teixeira, D. C., Jesus Junior, W. C., Ayres, A. J., Gimenes-Fernandes, N., Rabenstein, F., Girotto, L. F., and Bové, J. M. 2004. Sudden death of citrus in Brazil: A graft-transmissible bud union disease. Plant Dis. 88:453-467.

Citrus Sudden Death (CSD), a new, graft-transmissible disease of sweet orange and mandarin trees grafted on Rangpur lime rootstock, was first seen in 1999 in Brazil, where it is present in the southern Triângulo Mineiro and northwestern São Paulo State. The disease is a serious threat to the citrus industry, as $85 \%$ of 200 million sweet orange trees in the State of São Paulo are grafted on Rangpur lime. After showing general decline symptoms, affected trees suddenly collapse and die, in a manner similar to trees grafted on sour orange rootstock when affected by tristeza decline caused by infection with Citrus tristeza virus (CTV). In tristeza-affected trees, the sour orange bark near the bud union undergoes profound anatomical changes. Light and electron microscopic studies showed very similar changes in the Rangpur lime bark below the bud union of CSD-affected trees: size reduction of phloem cells, collapse and necrosis of sieve tubes, overproduction and degradation of phloem, accumulation of nonfunctioning phloem (NFP), and invasion of the cortex by old NFP. In both diseases, the sweet orange bark near the bud union was also affected by necrosis of sieve tubes, and the phloem parenchyma contained characteristic "chromatic" cells. In CSDaffected trees, these cells were seen not only in the sweet orange phloem, but also in the Rangpur lime phloem. Recent observations indicated that CSD affected not only citrus trees grafted on Rangpur lime but also those on Volkamer lemon, with anatomical symptoms similar to those seen in Rangpur lime bark. Trees on alternative rootstocks, such as Cleopatra mandarin and Swingle citrumelo, showed no symptoms of CSD. CSD-affected trees did recover when they were inarched with seedlings of these rootstocks, but not when inarched with Rangpur lime seedlings. These results indicate that CSD is a bud union disease. In addition, the bark of inarched Rangpur lime and Volkamer lemon seedlings showed, near the approach-graft union, the same anatomical alterations as the bud union bark from the Rangpur lime rootstock in CSD-affected trees. The dsRNA patterns from CSD-affected trees and unaffected trees were similar and indicative of CTV. CSD-affected trees did not react by immunoprinting-ELISA using monoclonal antibodies against 11 viruses. No evidence supported the involvement of viroids in CSD. The potential involvement of CTV and other viruses in CSD is discussed.
\end{abstract}

Additional keywords: Citrus aurantium, C. limonia, C. sinensis, C. volkameriana, pathological anatomy

Tristeza decline of citrus trees grafted on sour orange (Citrus aurantium L.) rootstock has been one of the most destructive diseases of citrus (33). Worldwide, 100 million trees have been killed by the dis-

Corresponding author: Mariano Cambra

E-mail: mcambra@ivia.es

M. P. Román and F. A. O. Tanaka contributed equally to this work.

Accepted for publication 9 December 2003.

Publication no. D-2004-0315-01R

(C) 2004 The American Phytopathological Society double-stranded RNA (dsRNA)-rich extracts $(2,26)$.

Tristeza decline is a bud union disease. Sweet orange and sour orange trees growing on their own roots are tolerant to most CTV isolates. A tristeza-sensitive tree is a combination of two partners separated by a bud union: a sweet orange (and many other citrus species and hybrids) scion grafted on a sour orange rootstock. Trees grafted on lemon (Citrus limon (L.) Burm.) are also sensitive to tristeza decline. However, lemon trees on sour orange rootstock do not develop decline. Certain strains of CTV are able to produce, besides tristeza decline, additional pathological effects: stem pitting $(16,29)$ and/or seedling yellows (12). Some strains of CTV, generally termed mild, do not induce the tristeza decline $(15,25)$, nor do they cause stem pitting. Control of tristeza has been based on the replacement of sour orange by rootstocks giving tolerant combinations with sweet orange and other citrus species, a procedure that has taken many years. Such alternative rootstock species include trifoliate orange (Poncirus trifoliata (L.) Raf.) and its hybrids (citranges, citrumelos), Cleopatra mandarin (C. reshni Hort. ex Tan), Sunki mandarin (C. sunki Hort. ex Tan), Volkamer lemon (Citrus volkameriana Ten. \& Pasq.), and Rangpur lime ( $C$. limonia Osb.), also called limão Cravo in Brazil. In the State of São Paulo, Brazil, the largest sweet orange growing region in the world, $85 \%$ of 200 million trees are grafted on Rangpur lime, because under São Paulo conditions citrus on this rootstock can be grown without irrigation.

In view of the importance of Rangpur lime in Brazil, the discovery in 1999 that sweet orange trees on this rootstock were rapidly declining and dying came as a shock (14). This new disease, which has taken on alarming proportions, was called "Morte Súbita dos Citros" or Citrus Sudden Death (CSD) (27), and resembled tristeza decline (7). It was first observed in the municipality of Comendador Gomes in the south of Triângulo Mineiro, Minas Gerais State (14). On the basis of extensive surveys by Fundecitrus, the total number 
of dead or affected trees was estimated to be more than one million in June 2003, and CSD was present not only in municipalities of the southern part of Triângulo Mineiro, but had also reached municipalities in the northwestern part of São Paulo State. CSD has been observed on all sweet orange varieties grown in the affected areas: Valencia, Pera, Hamlin, Natal, Westin, Rubi, and Pineapple. Trees on the major alternative rootstocks used in São Paulo State (Cleopatra and Sunki mandarins, Swingle citrumelo) are not affected. Recent observations have revealed that sweet orange trees on Volkamer lemon are also affected by CSD. This rootstock carries only $1 \%$ of all sweet orange trees, but as it is drought resistant, it could have been used as a replacement for Rangpur lime on nonirrigated farms.

The spatial and temporal increase of CSD-symptomatic trees has recently been analyzed and found to be strikingly similar to that of CTV-infected trees under conditions where T. citricida is the aphid vector (5). Also, for spatial autocorrelation analyses of proximity patterns, the results for CSD and CTV were remarkably similar. Because of these similarities, it has been suggested that CSD may be caused by an insect-vectored pathogen, such as a new strain of CTV or a virus other than CTV $(5,7)$. Transmission of CSD by graft inoculation has recently been obtained, and demonstrates that the disease is infectious and caused by a biotic agent (42). Here we show that the pathological anatomy at the bud union of CSD-affected sweet orange trees on Rangpur lime and Volkamer lemon is strikingly similar to that of tristeza-affected sweet orange trees on sour orange, as described by Schneider $(35,36)$. The same pathological anatomy is also observed at the graft union of Rangpur lime and Volkamer lemon seedlings approach-grafted to the sweet orange scions of CSD-affected sweet orange trees on Rangpur lime. These studies confirm that CSD, like tristeza decline, is a bud union disease. The fact that CSD, like tristeza, is a bud union disease, as well as the results from epidemiology and anatomy, suggest that a CTV strain rather than a new virus might be involved in CSD. However, RNA sequences with homology to a viral RNA from the family Tymoviridae have been recently detected in CSD-affected trees, but not in trees from the unaffected regions (Reinach F., Alellyx, Applied Genomics, public conference on CSD, 14 October 2003). The etiology of CSD is discussed in the light of these findings.

\section{MATERIALS AND METHODS}

Surveys for CSD-affected trees were carried out from April to August 2003 as described in Bassanezi et al. (5).

Bark samples for histological analysis. 1) Scion and rootstock bark. Rectangular pieces of bark $(3 \mathrm{~cm}$ high, $1 \mathrm{~cm}$ wide) were collected $3 \mathrm{~cm}$ above and $3 \mathrm{~cm}$ below the bud union lines of symptomless and symptomatic trees. In the case of CSD, samples were from trees with level 1 and level 2 decline. In trees with level 1 decline, symptoms are mild, leaves turn pale green and loose their shininess, some defoliation occurs, and Rangpur lime and Volkamer lemon bark below the bud union are light yellow. In level 2 decline, symptoms are severe, defoliation is pronounced, rootstock bark is bright yellow, and root rot is conspicuous. The following trees were sampled:

(i) Five symptomless and five level 2 CSD-affected, 8-year-old Pera sweet orange trees on Rangpur lime rootstock, and five 8-year-old symptomless Pera sweet orange trees on Cleopatra mandarin rootstock from Comendador Gomes (south of Triângulo Mineiro, Minas Gerais State, Brazil), the center of the CSD-affected region (Fig. 1: 5).

(ii) Five 8-year-old Pera sweet orange trees on Rangpur lime rootstock, and five 8-year-old Pera sweet orange trees on Cleopatra mandarin rootstock from Matão (central São Paulo State, Brazil), a CSDfree region $250 \mathrm{~km}$ south of Comendador Gomes (Fig. 1: M).

(iii) Five severely declining tristezaaffected 8-year-old Navelate sweet orange trees on sour orange rootstock from Picassent, a CTV-affected region near Valencia, Spain.

(iv) Three symptomless, three level 1 CSD-affected, 6-year-old Valencia sweet orange trees on Volkamer lemon, and three 3-year-old, CSD-affected (level 2) Valencia sweet orange trees on Volkamer lemon from Colombia, São Paulo (Fig. 1: 12).

The rootstock bark of all CSD-affected trees showed the characteristic yellow stain associated with CSD.

2) Bark from approach-grafted Rangpur lime, Volkamer lemon, and Cleopatra mandarin seedlings. One-year-old seedlings were approach-grafted in November 2001. Rangpur lime and Cleopatra mandarin bark samples were collected in January 2003, and C. volkameriana bark, in June 2003.

(i) Two Rangpur lime seedlings were inarched to a CSD-affected Valencia sweet orange tree on Rangpur lime rootstock planted in 1997 in the Colombia region (Fig. 1: 12); at the time of collection, bark of the two seedlings was yellow, but bark from seedling 1 already showed the yellow discoloration in June 2002 and was used for examination.

(ii) Three Cleopatra mandarin seedlings were approach-grafted to a similar CSDaffected Hamlin sweet orange tree on Rangpur lime from the same plot; bark from inarched seedling 1 was used for analysis.

(iii) Three Rangpur lime seedlings were approach-grafted to an 8-year-old CSDaffected Hamlin sweet orange tree on
Rangpur lime rootstock (Fig. 2G) in the Comendador Gomes region; the bark from all three inarched seedlings was used for anatomical examination; bark of seedling 2 showed yellow discoloration.

(iv) Three Volkamer lemon seedlings were inarched to an 8-year-old, CSDaffected Hamlin sweet orange tree on Rangpur lime. Two of the three inarched seedlings showed conspicuous yellow discoloration at the graft union.

Rectangular bark pieces ( $1 \mathrm{~cm}$ wide, 2 $\mathrm{cm}$ high) were collected from the seedlings, opposite to the side of the approachgraft union (Fig. 2G, arrows), at three different distances $(0,6$, and $10 \mathrm{~cm})$ below the union. Distance " 0 " corresponds to the arrowheads of Figure 2G.

Bark sample treatment for histological analysis by light and electron microscopy. The large bark pieces $(3 \times 1 \mathrm{~cm})$ were cut into six smaller $(0.5 \times 1 \mathrm{~cm})$ pieces for better fixation. For light microscopy, fixation of all bark samples was in FAA solution (formaldehyde, ethanol, acetic acid, in the proportion of 0.5:9:0.5, $\mathrm{vol} / \mathrm{vol} / \mathrm{vol})$. After 15 days, dehydration was made through a series of ethanol/tertiary butyl alcohol solutions (18). The samples were embedded in paraffin plasticized pellets (melting point: 56 to $58^{\circ} \mathrm{C}$ ) (Panreac Química SA, Barcelona, Spain). Ten micrometer thick bark cross sections (plane of section perpendicular to axis of tree trunk or seedling stem) were obtained with a rotary microtome (Jung, Germany). Staining of the sections was with a combination of safranin O (Merck, Darmstadt, Germany) (lignified cellular walls stain red) and Fast Green FCI (Sigma Chemical Co., St. Louis, MO, USA) (cellulose stains blue-green) and mounted with Canada balsam (Merck) $(18,19)$. Sections were examined with a Nikon Eclipse E800 microscope equipped with photomicrographic H-III (Mode C) and Digital still camera DXH1200 (Nikon, Tokyo, Japan).

For electron microscopy, tissues were cut into small pieces $(1 \times 3 \mathrm{~mm})$ and fixed in a modified Karnovsky fixative $(2.5 \%$ glutaraldehyde, $2 \%$ paraformaldehyde in $0.05 \mathrm{M}$ cacodylate buffer, $\mathrm{pH} 7.2$, and $0.001 \mathrm{M} \mathrm{CaCl}_{2}$ ), postfixed in $1 \% \mathrm{OsO}_{4}$ in the same buffer, stained in block with $0.5 \%$ uranyl acetate, dehydrated in acetone, and embedded in Spurr's low viscosity resin (Electron Microscope Sciences, Fort Washington, PA, USA). Thin sections were produced in a Leica Ultracut $\mathrm{T}$ microtome equipped with a diamond knife (Leica, Wien, Austria), stained with $3 \%$ aqueous uranyl acetate and Reynold's lead citrate (Sigma), and examined in a Zeiss EM 900 transmission electron microscope (TEM) (Zeiss, Oberkochen, Germany). For scanning electron microscopy (SEM), tissues were fixed in a mixture of $2.5 \%$ glutaraldehyde, $2 \%$ paraformaldehyde in $0.05 \mathrm{M}$ cacodylate buffer, $\mathrm{pH} 7.2$, infiltrated with $30 \%$ glycerol, frozen in liquid nitrogen, 
fractured, postfixed with $1 \% \mathrm{OsO}_{4}$, dehydrated in acetone, critical point dried with a Balzers CPD 050 dryer (Balzers Instruments, Liechtenstein), mounted on aluminum stubs, sputter-coated with gold (Balzers MD 010 evaporator), and examined in a LEO 435 VP (Cambridge, UK) scanning electron microscope.

Part of the samples processed for TEM were also prepared for light microscopy. After fixation in Karnovsky solution and dehydration in ethanol, tissues were infiltrated and embedded in the acrylic resin JB-4 (Electron Microscope Sciences) or Historesin (Leica), sectioned (5 to $8 \mathrm{~mm}$ thick) in a Leica microtome with a steel knife, mounted on glass slides, and stained with acidic toluidine blue.

Double-stranded RNA profiles, singlestrand conformation polymorphism analysis, and viroid detection. DsRNArich extracts were prepared from total nucleic acid extracts of bark from young scion shoots by nonionic cellulose column chromatography in the presence of $16.5 \%$ ethanol under the conditions previously described (26) and analyzed by polyacrylamide gel electrophoresis (PAGE) (5\% acrylamide). Extracts were obtained from 23 field trees, 20 of which were sampled from citrus plantings affected by the disease in the Comendador Gomes region, and three from a citrus planting in the CSD-free Matão region. Within the first group, one Ponkan mandarin (C. reticulata Blanco) and seven sweet orange trees were grafted on Rangpur lime and showed no symptoms; four sweet orange trees also on Rangpur lime showed level 1 decline; and three trees on the same rootstock showed level 2 decline. Two Hamlin sweet orange trees were propagated on trifoliate orange; one of them was symptomless and the other showed a severe decline, different than CSD, with no yellow stain in the rootstock bark, and probably due to a severe
CTV strain (it showed conspicuous stem pitting in the branches). Two symptomless Valencia sweet orange trees were propagated on Cleopatra mandarin. The last sample consisted of Volkamer lemon sprouts from a tree whose canopy had died from an unknown cause. The three trees from the nonaffected area included a Pera sweet orange on Rangpur lime and two Natal sweet orange trees on Swingle citrumelo rootstock.

A preliminary characterization of the CTV population infecting all sampled trees was accomplished by single strand conformation polymorphism (SSCP) analysis of DNA complementary to the p20 gene (34) using as control the CTV isolate T388 from the Instituto Valenciano de Investigaciones Agrarias collection. For this purpose, the cDNA was obtained by reverse transcription (RT) and amplification by polymerase chain reaction (PCR) using dsRNArich extracts as template and primers

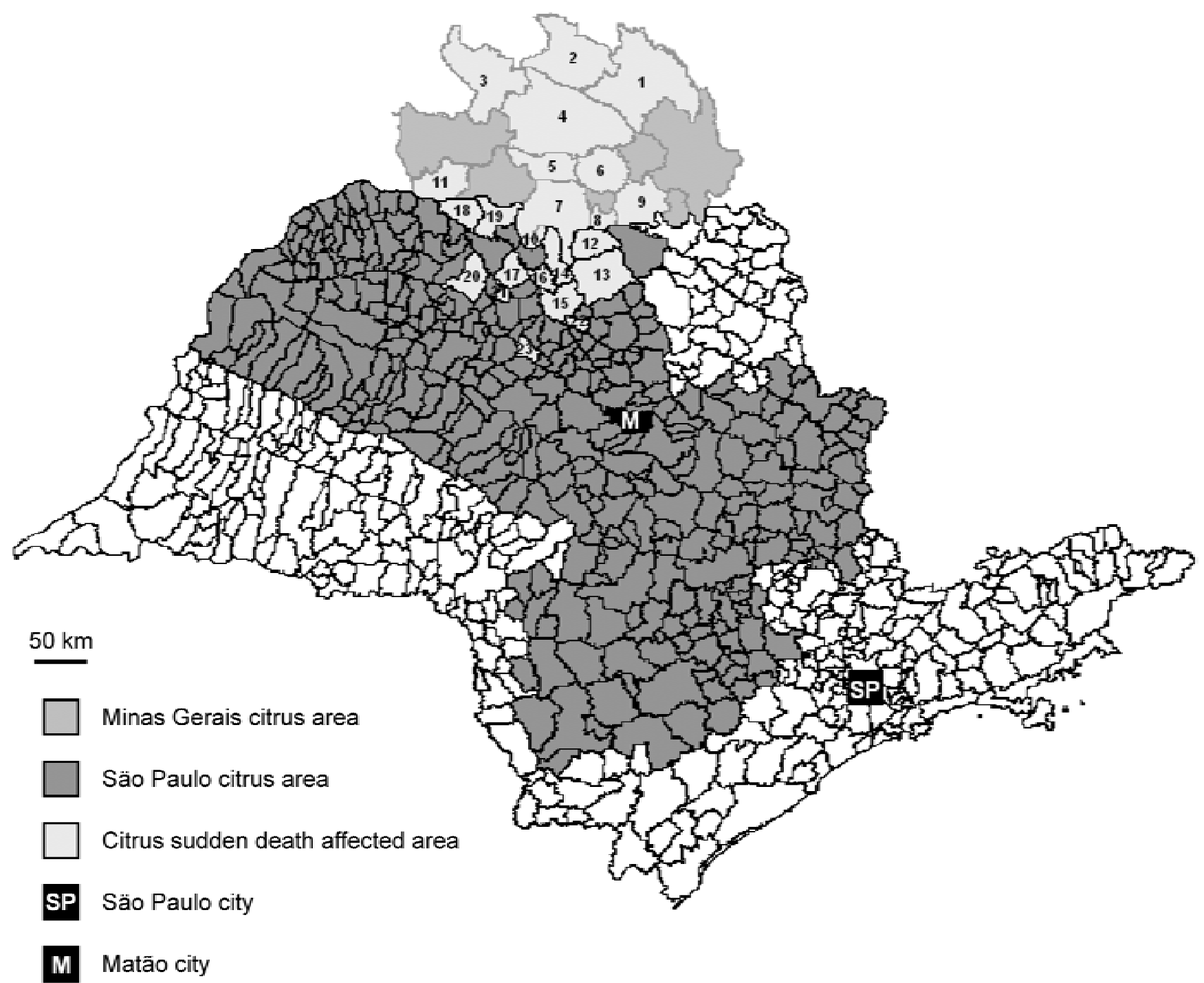

Fig. 1. Map showing extent of Citrus Sudden Death (September 2003). Numbers refer to affected municipalities in the southern part of Triângulo Mineiro and northwestern part of São Paulo. Southern Triângulo Mineiro: 1, Uberlândia; 2, Monte Alegre de Minas; 3, Ituiutaba; 4, Prata; 5, Comendador Gomes; 6, Campo Florido; 7, Frutal; 8, Planura; 9, Conceição das Alagoas; 10, Fronteira; and 11, São Francisco de Sales. Northwestern São Paulo State: 12, Colômbia; 13, Barretos; 14, Altair; 15, Olímpia; 16, Guaraci; 17, Nova Granada; 18, Riolândia; 19, Paulo de Faria; 20, Tanabi; 21, Ipigua; 22, Cajobi; and 23, Ibira. M = Matão City. SP = São Paulo City. 

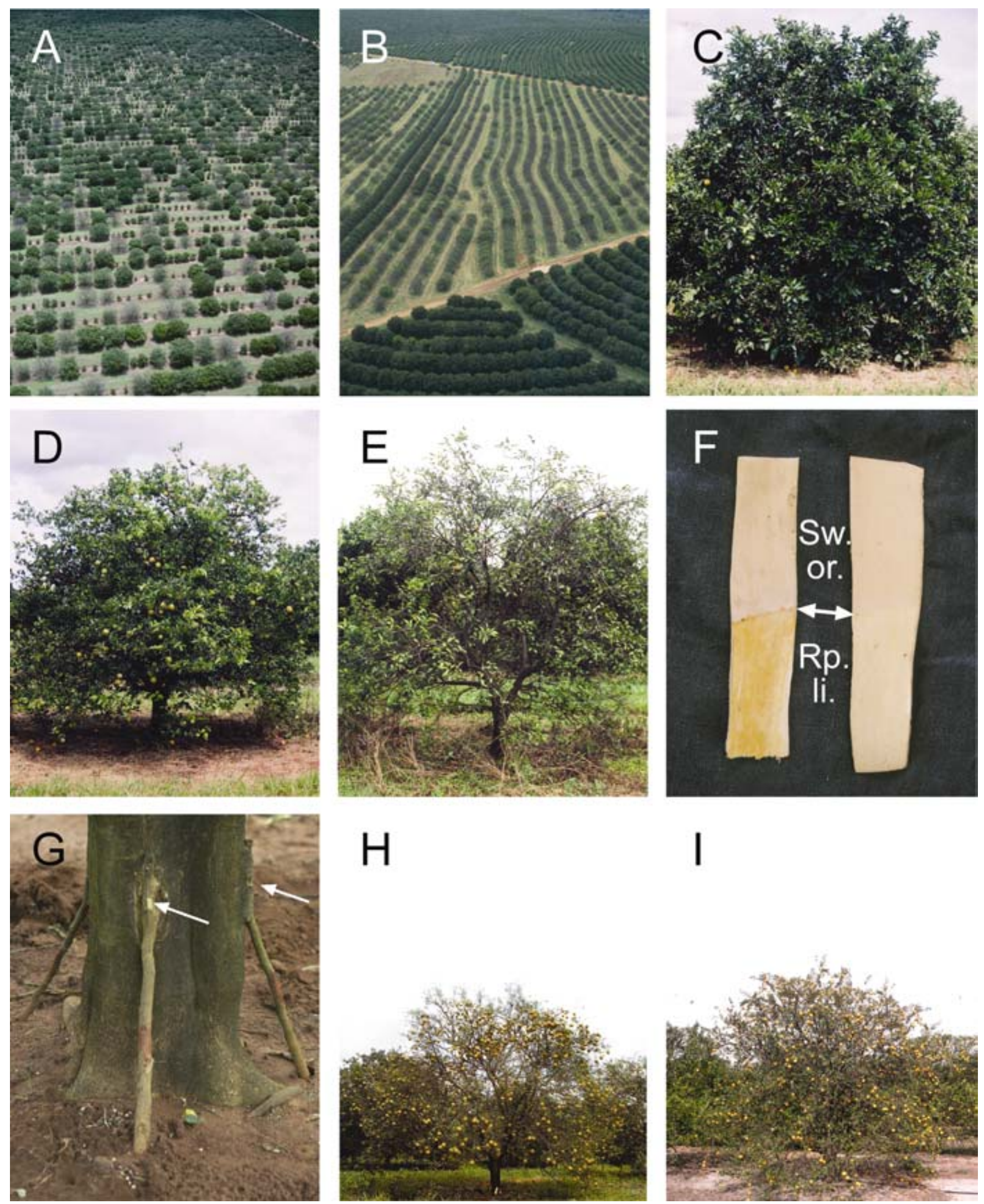

Fig. 2. Symptoms of Citrus Sudden Death (CSD). A, Aerial view of CSD-affected sweet orange trees on Rangpur lime rootstock at various stages of decline. Many trees have been pulled out and replaced by young trees on Cleopatra mandarin or Swingle citrumelo rootstocks. B, Aerial view of a sweet orange plantation with green, unaffected trees on Cleopatra mandarin (trees in foreground and background, and the two rows of trees at left), and pale-green, CSD-affected trees on Rangpur lime. C, Unaffected Valencia sweet orange tree on Rangpur lime. D and E, CSD-affected Valencia sweet orange trees on Rangpur lime with symptoms of severity levels 1 (D) and 2 (E) (See text). F, Bud union bark of CSD-affected (left) and unaffected (right) Valencia sweet orange trees on Rangpur lime. Arrowheads point at bud union line. Cambial face of CSD-affected Rangpur lime bark shows yellow discoloration. Sw. or. $=$ sweet orange. Rp. li. $=$ Rangpur lime. G, CSD-affected Hamlin sweet orange tree on Rangpur lime inarched with three Rangpur lime seedlings: seedling 2 (right) had yellow stain at position indicated by arrow (distance, $0 \mathrm{~cm}$ ); seedlings 1 (center) and 3 (left) displayed no yellow stain. H, CSD-affected Valencia sweet orange tree on Rangpur lime (Comendador Gomes, Minas Gerais). I, Tristeza-affected Valencia sweet orange tree on sour orange (Ashland, FL, USA). 
specific for the p20 gene, followed by SSCP-analysis as previously described $(3,34)$.

In the search for viroid and viroid-like RNAs, the same bark samples were homogenized and total nucleic acids were partitioned in $2 \mathrm{M} \mathrm{LiCl} \mathrm{(37).} \mathrm{The} \mathrm{soluble}$ fraction was concentrated by ethanol precipitation, resuspended in TKM buffer (10 $\mathrm{mM}$ Tris- $\mathrm{HCl} ; 10 \mathrm{mM} \mathrm{KCl} ; 0.1 \mathrm{mM}$ $\mathrm{MgCl}_{2}, \mathrm{pH}$ 7.4), and subjected to sequential 5\% PAGE (32) and silver staining (17). Samples from trees showing bark-scaling characteristic of exocortis on the Rangpur lime rootstock were used as positive controls. These trees were located in an orchard severely affected by CSD.

Serological analysis. Fruit peduncles (10 peduncles per tree) and bark pieces from the scion and the rootstock $(3 \mathrm{~cm}$ above and below the bud union) were collected from the 23 trees described above. In addition, equivalent bark samples were also collected from CTV-affected and -unaffected sweet orange trees grafted on sour orange rootstock growing at Picassent (Valencia, Spain). The samples were homogenized in phosphate-buffered saline (PBS), pH 7.4, containing $0.2 \%$ sodium diethyl dithiocarbamate (DIECA) (1w:60v for peduncles; $1 \mathrm{w}: 20 \mathrm{v}$ for bark) for double antibody sandwich indirect enzyme-linked immunosorbent assay (DASI-ELISA) (8) using the mixture of the CTV-specific monoclonal antibodies 3DF1 and 3CA5 (40) for universal detection of CTV (9) (Ingenasa, Madrid, Spain), and MCA13 for specific identification of the more severe isolates (30). Samples were tested in quadruplicate.

The fruit peduncles from the 23 trees were also imprinted on nitrocellulose membranes $(10,13)$ and processed using a commercial kit (Plant Print Diagnostics, Valencia, Spain). Additional leaf petiole imprints were prepared from trees of CSDaffected and unaffected regions. Samples from the affected region included symptomatic and asymptomatic trees of Hamlin, Natal, and Pera sweet orange trees on Rangpur lime, and symptomless Natal and Pera on Cleopatra mandarin. Samples from the unaffected region included Hamlin, Natal, and Pera sweet orange trees on Rangpur lime and Cleopatra mandarin rootstocks. These samples were analyzed by tissue print-ELISA using the specific monoclonal antibodies 3DF1 and 3CA5 described above as well as 41 monoclonal antibodies against the following 11 viruses: Barley yellow dwarf virus (BYDV), Bean leaf roll virus (BLRV), Beet mild yellowing virus (BMYV), Beet western yellows virus (BWYV), Beet yellows virus (BYV), $\mathrm{Cu}$ cumber mosaic virus (CMV), Peanut stunt virus (PSV), Potato leaf roll virus (PLRV), Potato virus $Y$ (PVY), Ryegrass mosaic virus (RNV), and Turnip yellow virus (TuYV). In addition, potyvirus-group specific monoclonal antibodies (31) were also used.

\section{RESULTS}

Geographical distribution of CSD. CSD started in 1999 in the municipality of Comendador Gomes (Fig. 1: 5) in the southern part of the Triângulo Mineiro in Minas Gerais State. In June 2003, 10 additional municipalities of the Triângulo Mineiro were affected (Fig. 1: 1 to 4, 6 to 11 ), and the disease was present in seven municipalities of northwestern parts of São Paulo State (Fig. 1: 12 to 18). Further surveys showed that by September 2003, the disease occurred in five additional municipalities (Fig. 1: 19 to 23), two of which (Fig. 1: 22 and 23) represented the most southern affected municipalities. The affected areas in the Triângulo Mineiro are within a region that is considered marginal for citrus because of its high summer temperatures and relatively poor soils, and it was speculated that the disease would stay within that region. Unfortunately, from the recent surveys, it appears that CSD is moving south and entering the major citrus belt of São Paulo State.

CSD symptoms of sweet orange trees on Rangpur lime rootstock. Even before any external CSD symptoms can be seen, the phloem tissue of the Rangpur lime bark below the bud union becomes yellow (14). On some trees, the yellow discoloration was seen directly on the cambial face of the bark (Fig. 2F), whereas on others, the stain affected more external phloem tissues and could be visualized on a piece of bark by scratching away the whitish cambial tissue layers. The yellow discoloration seems to be a consistent symptom of the disease and is conveniently used to distinguish CSD from other decline diseases such as "declinio", the Brazilian name for citrus blight. The youngest trees that showed the characteristic yellow stain were 22 months old. However, a Rangpur lime seedling inarched in November 2001 to a CSD-affected 5-year-old tree developed the yellow bark discoloration near the approach-graft union as early as 7 months after inarching. This discoloration has not been seen in sour orange rootstock bark from the bud union of tristeza-affected trees.

Several levels of disease severity were seen in the field (Fig. 2A and B). In comparison with symptomless trees (Fig. 2C), level 1 trees (Fig. 2D) have initial symptoms: the phloem tissue below the bud union is light yellow, leaves lose their shininess and turn pale green, there is not much defoliation, but some root rot is observed. In level 2 (Fig. 2E), symptoms have become severe, trees show pronounced defoliation, root rot has progressed, and the intensity of the stain in the bark has increased to bright yellow (Fig. 2F). In level 3, trees are almost dead, with severe defoliation and root rot. Leaves and fruit remain attached to trees that have suddenly collapsed (Fig. 2H). The rates of symptom development and tree collapse are more pronounced in the spring, at the beginning of the rainy season (5).

The external symptoms of CSD-affected sweet orange trees were very similar to those of tristeza-affected sweet orange trees on sour orange as they can be seen, for instance, in Florida today (Fig. 2I compared with Fig. 2H). Progress of the disease resulting in tree collapse was very similar in CSD and tristeza. In the case of tristeza, not only sweet orange, but also other citrus cultivars, such as mandarins and grapefruits, produce sensitive combinations when grafted on sour orange. As expected, it was recently observed that Ponkan and Cravo mandarin trees, when grafted on Rangpur lime, also succumb to CSD in the affected regions.

Sensitivity of Rangpur lime to the CSD pathogen. In 2002, a few normal, symptomless Rangpur lime trees were observed within rows of CSD-affected trees. Most likely, these Rangpur lime trees were initially carrying sweet orange buds, but the buds failed to develop and the Rangpur lime rootstocks took over. Also, when the sweet orange scions of some CSD-affected trees were experimentally cut off below the bud union, the remaining Rangpur lime rootstock produced vigorous, symptomless shoots. However, after about 18 months, both the Rangpur lime trees and the grown-up shoots from the cut-off trees began to show some yellow leaves, as well as some yellow stain in the bark. Recently, Rangpur lime trees were found in various backyards in the affected area, and they also showed the same symptoms, but without any indication of collapse or sudden death. None of these symptoms were seen on Rangpur lime trees growing in the region unaffected by CSD. It therefore seems that Rangpur lime is sensitive to the agent of CSD.

CSD symptoms of sweet orange trees on Volkamer lemon rootstock. In June 2003, about one hundred Valencia sweet orange trees on Volkamer lemon in four blocks of a farm severely affected by CSD near Colombia (Fig. 1: 12) showed level 1 and level 2 symptoms very similar to those of CSD-affected trees on Rangpur lime, including root symptoms. At the conclusion of the study, no trees showing level 3 symptoms had been seen. Scion leaves with yellowish midveins were more frequent with trees on Volkamer lemon than with those on Rangpur lime. All symptomatic trees revealed the characteristic yellow stain in the Volkamer lemon bark below the bud union. In level 2 trees, the yellow stain was more intense than in level 1 trees. Symptomless trees in the affected and nonaffected regions did not carry the stain. Affected trees were 3 and 6 years old, whereas 12-year-old Valencia sweet orange trees on Volkamer lemon in the same farm did not yet show symptoms of CSD. All of 25 Volkamer lemon seedlings inarched in November 2001 to CSD- 
affected 8-year-old Hamlin sweet orange trees on Rangpur lime showed in June 2003 the yellow bark stain at the approachgraft union. No yellow stain was observed in Volkamer lemon seedling trees growing close to CSD-affected trees, but they were only 18 months old. From these results, it seems as if the yellow stain, present in both Rangpur lime and Volkamer lemon bark and only in CSD-affected trees, was characteristic of CSD.

Bark anatomy at bud union of trees grafted on Rangpur lime, Cleopatra mandarin, and sour orange. Cross sections of scion bark from Pera and Navelate sweet orange, and rootstock bark from Rangpur lime, Cleopatra mandarin, and sour orange near the bud union of affected and unaffected trees were analyzed by light microscopy. For each type of affected and unaffected scion-rootstock combination, the bark from five similar field trees was examined. Figures 3 and 4 correspond each to the most representative tree, and details of selected parts of these figures are given on Figures 5 and 6. Rangpur lime rootstock bark near the bud union was also examined by electron microscopy (Fig. 7).

Figure $3 \mathrm{~A}$ and $\mathrm{B}$ is representative of normal Pera sweet orange scion bark (A) and normal Rangpur lime rootstock bark (B) near the bud union of trees from the CSD-free Matão region (see Fig. 1). The functioning phloem (FP) was well developed, and there was good equilibrium between the FP and the nonfunctioning phloem (NFP). In the FP of both Rangpur lime bark (Fig. 5A) and Pera sweet orange bark (Fig. $5 \mathrm{H}$ ), the sieve tubes had a clear content, the medullar rays were straight and were approximately three cells in width. Similar normal tissue characteristics applied also to the bud union bark of the following trees (data not shown): Pera sweet orange trees on Cleopatra mandarin rootstock, whether the trees were from the affected or the unaffected regions; symptomless Pera sweet orange trees on Rangpur lime from the CSD-affected region; tristeza-free Navelate sweet orange trees on sour orange from Picassent, Spain.

The bud union bark of CSD-affected trees showed profound pathological changes in comparison with normal bark.<smiles></smiles>

\section{RANGPUR}

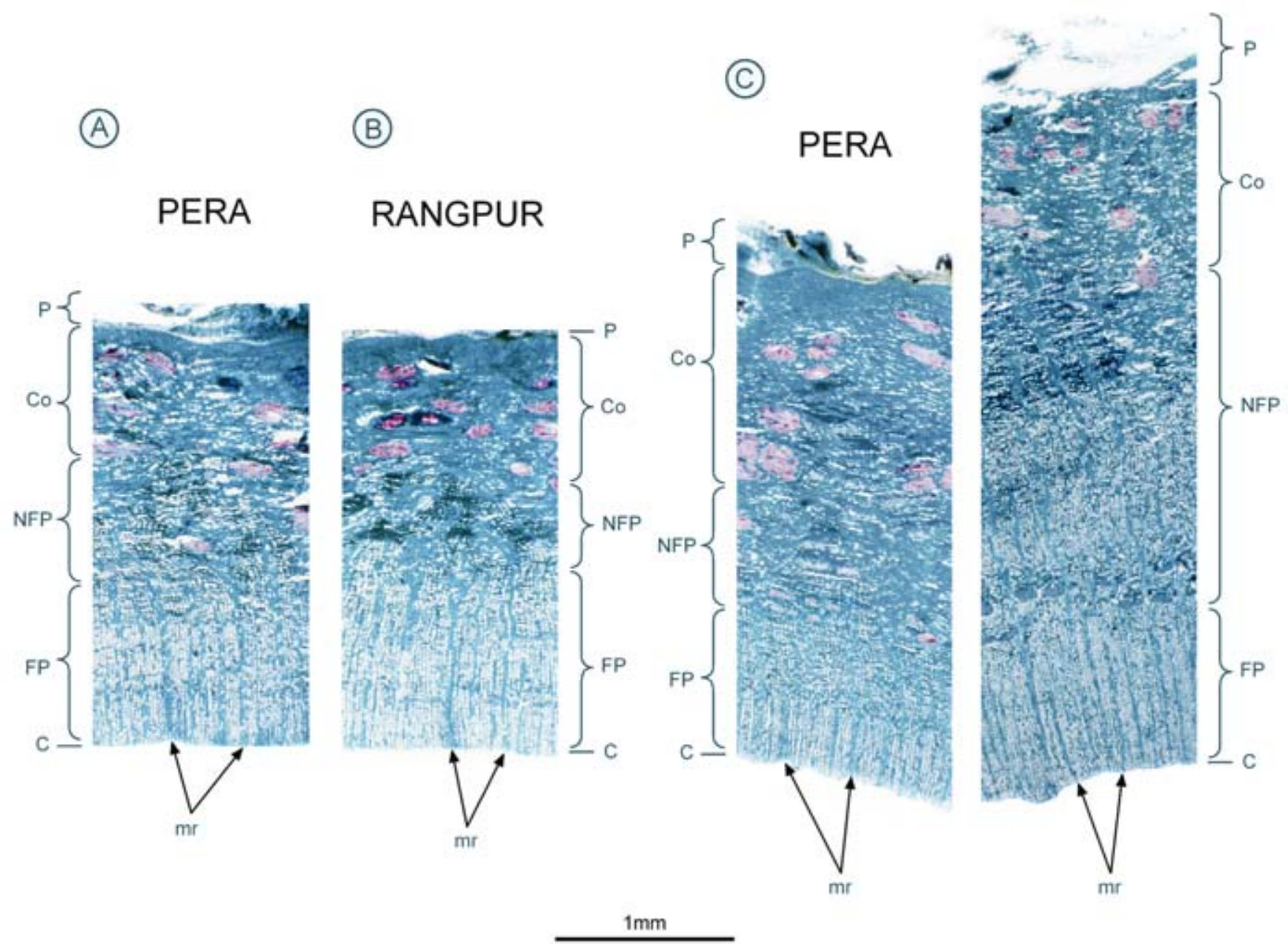

Fig. 3. Symptomless Pera sweet orange trees on Rangur lime rootstock from Matão (Citrus Sudden Death [CSD]-free region) (A and B) and Comendador Gomes (CSD-affected region) (C and D). Cross section through bud union bark of sweet orange (A and C) and Rangpur lime (B and D). C = cambium; Co $=$ cortex $; \mathrm{FP}=$ functioning phloem $; \mathrm{mr}=$ medullar rays; $\mathrm{NFP}=$ nonfunctioning phloem; $\mathrm{P}=$ peridermis. $\mathbf{A}$, Normal tissue characteristics. Good equilibrium between FP and NFP. Collapse of old phloem tissue only. In FP, straight, medullar rays, three cells in width. Curved rays in NFP. Cortex with fiber bundles and normal parenchymatic tissue. Thin peridermis with lenticels. B, Same characteristic as in A, except larger FP zone. C, Section is similar to section $\mathbf{A}$, except for thicker cortex. D, Thickness of the bark almost twice that of section B. Accumulation of NFP. Even though this section comes from a symptomless tree, it shows early histological symptoms. Medullar rays, peridermis, and cortex still normal as in B. See details in Figure 5C. 
An excessive amount of NFP was present, not only in the Rangpur lime rootstock bark (Fig. 4B), but also in the sweet orange scion bark (Fig. 4A). The high amount of NFP accounts for the increased thickness of bark above and especially below the bud union of trees severely affected by CSD (Fig. 4A and B), in spite of the fact that the phloem cells in the affected bark (Fig. 5B) have a much smaller size than those in the normal bark (Fig. 5A). Thickness of bark pieces removed across the bud union of 20 sweet orange trees on Rangpur lime and as many on Cleopatra mandarin was measured $2 \mathrm{~cm}$ below and $2 \mathrm{~cm}$ above the bud

(B)
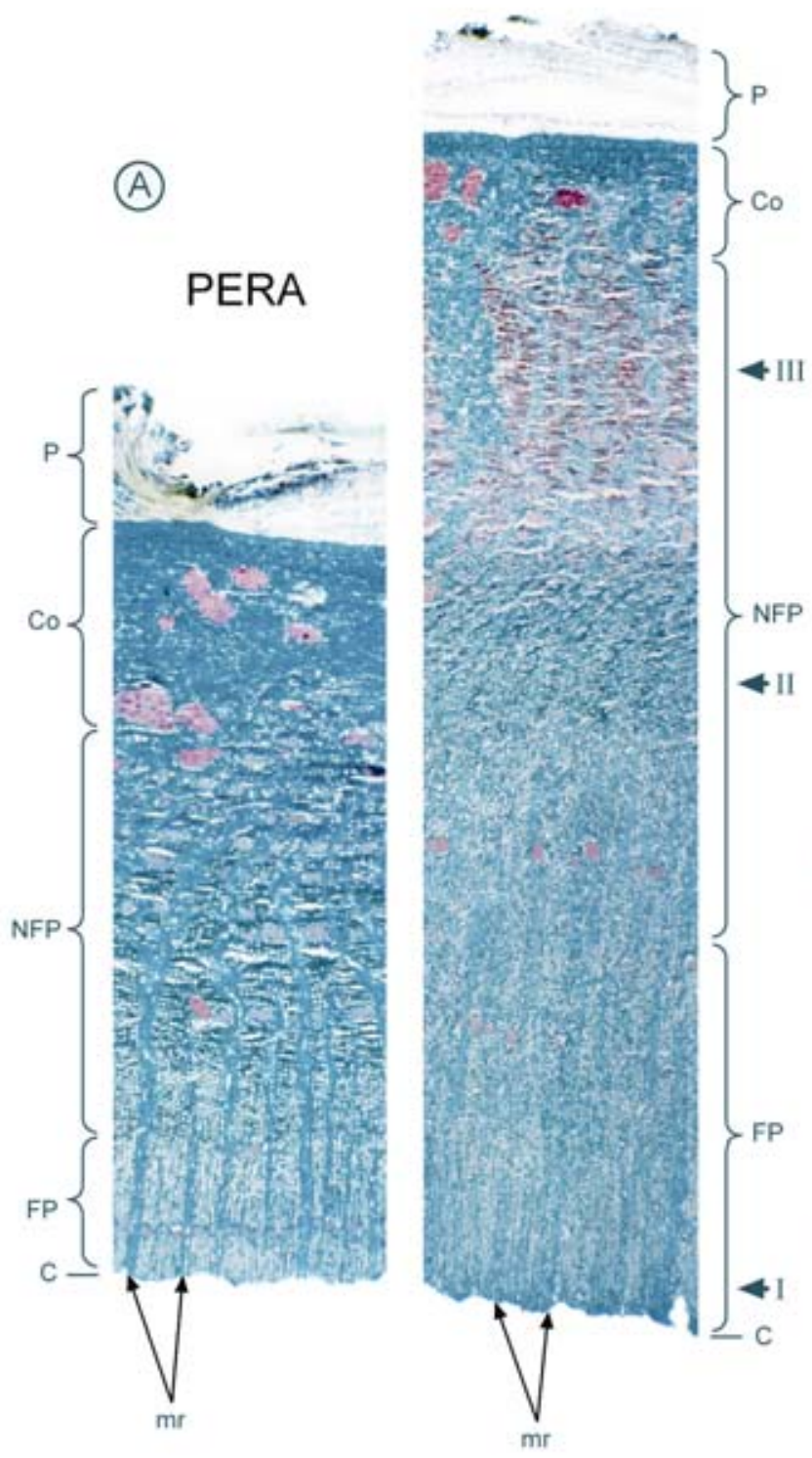

(C)

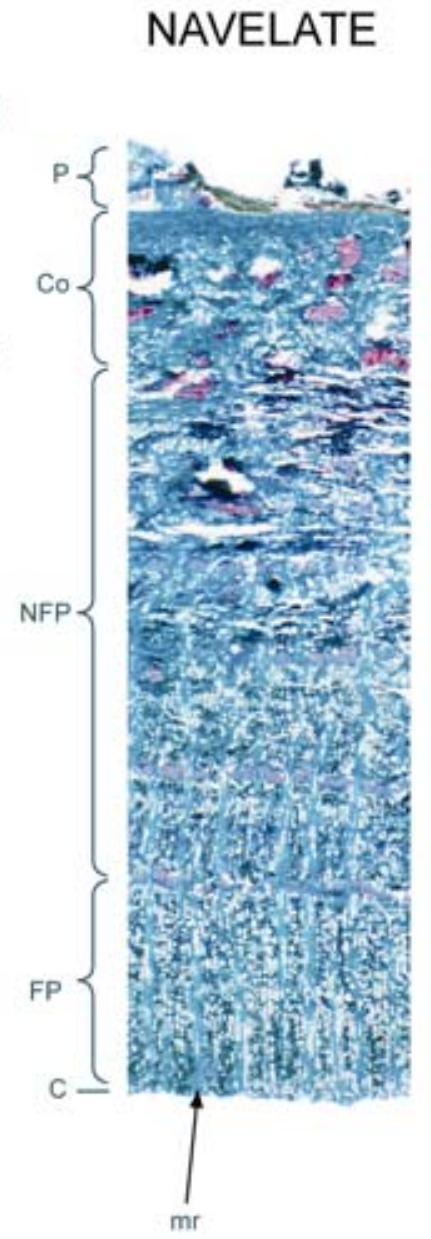

(D)

\section{SOUR ORANGE}

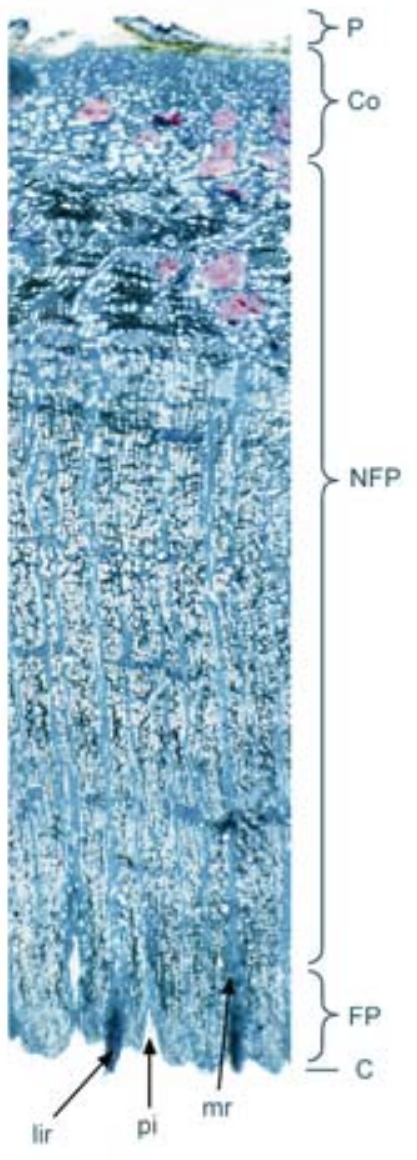

$1 \mathrm{~mm}$

Fig. 4. Symptomatic Pera sweet orange tree on Rangur lime rootstock (severity level 2) from Comendador Gomes (Citrus Sudden Death [CSD]-affected region) (A and B), and symptomatic Navelate sweet orange tree on sour orange rootstock from Picassent (CTV-affected region) in Spain (C and D): Cross section through bud union bark of $\mathbf{A}$, Pera sweet orange, $\mathbf{B}$, Rangpur lime, $\mathbf{C}$, Navelate sweet orange, and $\mathbf{D}$, sour orange. $\mathbf{C}=\mathrm{cambium} ; \mathrm{Co}=\mathrm{cortex} ; \mathrm{FP}=$ functioning phloem; lir = lignified phloem ray; $\mathrm{mr}=$ medullar rays; NFP = nonfunctioning phloem; $\mathrm{P}=$ peridermis; pi = pit. I, II, and III on section $\mathbf{B}$ indicate location of enlargements presented in Figure 5B, D to G. A, Overproduction of phloem, accumulation of NFP. Oldest NFP invading cortex. Peridermis with several layers of suber. See details in Figure 5I. B, Excessive amount of NFP, accounting for bark thickness. Cortex invaded by oldest NFP. Thin cortex with hypertrophic parenchyma cells. Peridermis with overproduction of suber. See details in Figure 5B, D to G. C, Accumulation of NFP, oldest NFP invading cortex, with concomitant tissue crushing. Large amounts of schlerenchyma tissue in NFP and fiber bundles in cortex. In most recent NFP, rays become already curved and are widened. Wide peridermis with large lenticels. D, Narrow band of FP with obliterated elements (see details in Figure 6H and I). High overproduction of phloem resulting in abundant NFP responsible for increase of bark thickness. Oldest NFP with many obliterated elements, invading cortex, and resulting in crushed tissues. In FP, rays are hyperplastic and some are lignified (lir) near cambial zone. Other lignified rays remain attached to the xylem, resulting in pits (pi) when bark is removed. Fiber bundles in cortex, and abundant schlerenchyma tissue in NFP. 

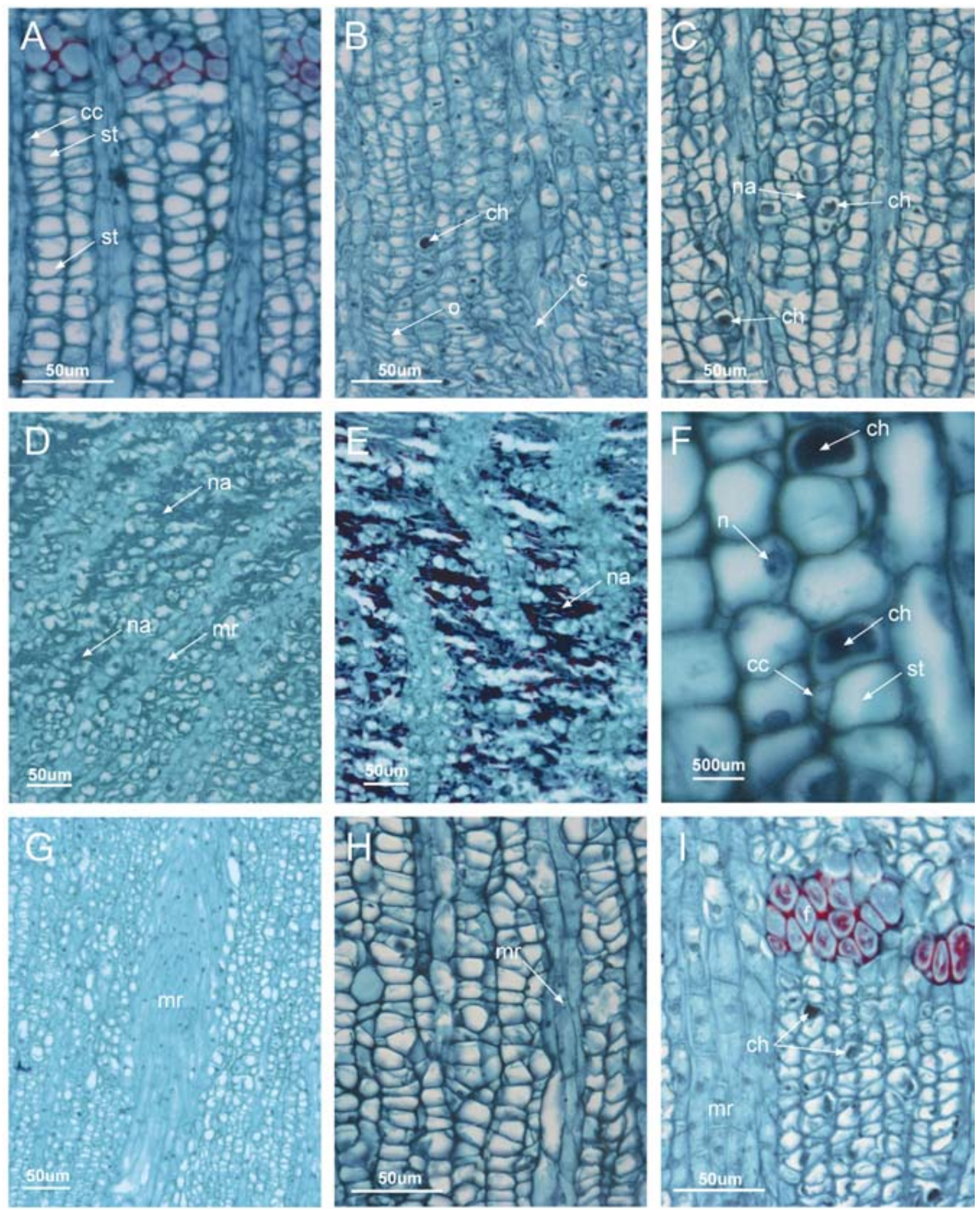

Fig. 5. Cross section of bud union bark of Citrus Sudden Death (CSD)-affected and nonaffected Pera sweet orange trees on Rangpur lime from Matão (CSD-free area) and Comendador Gomes (CSD-affected area). Rangpur lime phloem from symptomless trees at Matão (A) and Comendador Gomes (C), and from a symptomatic tree at Comendador Gomes (B, D, E, F, and G: respectively, enlargements from zones I, II, III, I, and I of Figure 4B). Pera sweet orange phloem from a symptomless tree at Matão $(\mathrm{H})$ and a symptomatic tree at Comendador Gomes $(\mathrm{I}) . \mathrm{c}=$ collapsed cells; $\mathrm{cc}=\mathrm{companion}$ cell; $\mathrm{ch}=\mathrm{chromatic}$ cells; $\mathrm{f}=$ fiber; $\mathrm{mr}=$ medullar rays; $\mathrm{n}=$ nucleus; $\mathrm{na}=$ necrotic areas; $\mathrm{o}=$ obliterated cells; $\mathrm{st}=$ sieve tube. A, Rangpur lime FP of Figure 3B. Normal sieve tubes and companion cells (cc), and sieve tubes (st) with clear content. B, Rangpur lime FP. Zone I of Figure 4B. Cells are small compared to those of A and C. Areas of collapsed (c) and obliterated (o) sieve tubes, and chromatic cells (ch). C, Rangpur lime FP of Figure 3D. Parenchymatic cells with dark content (chromatic cells) (ch); and necrotic areas (na). D, Rangpur lime NFP. Zone II of Figure 4B. Curved medullar rays (mr) and necrotic areas (na). E, Rangpur lime NFP. Zone III of Figure 4B. Old NFP. Important necrotic areas (na) with lignified phloem elements. F, Rangpur lime FP. Zone I of Figure 4B. Chromatic cells (ch) next to sieve tubes (st) and companion cells (cc). Nucleus (n) of parenchyma cell. G, Rangpur lime FP. Zone I of Figure 4B. Hyperplastic medullar ray. H, Pera sweet orange FP. Figure 3A. Young functioning phloem. Normal medullar ray (mr), three cells in width. I, Pera sweet orange FP. Figure 4A. Young FP. Chromatic cells (ch) similar to those of B. Hyperplastic medullar ray (mr) up to six cells in width. Bundles of phloem fibers (f). 
union line. The data obtained confirmed the twofold to threefold increase in bark thickness of CSD-affected trees compared with bark thickness from unaffected trees.

Pronounced pathological effects were observed in the young FP of bud union bark from CSD-affected trees. Sieve tubes and companion cells in the young FP of Rangpur lime bark (Fig. 4B: zone I) were obliterated or had collapsed, and became necrotic (Fig. 5B). Electron microscopy showed the sieve tubes and companion cells to be filled with amorphous material, and the lumen of phloem parenchyma cells to contain many rhomboedric crystals (Fig. 7A to C), whereas sieve tubes of Rangpur lime bark from nonaffected trees were empty (Fig. 7F). Sieve tubes with amorphous material and crystals were found in both FP and degraded NFP. Chromatic cells, i.e., phloem parenchyma cells whose content stains dark in microscopic preparations, occurred adjacent to sieve tubes in the FP of Pera sweet orange bark (Fig. 5I) as well as of Rangpur lime bark (Fig. 5B and F). Hyperplastic and/or hypertrophic medullar rays were seen in the young FP of Rangpur lime bark (Fig. 5G), as well as of sweet orange bark of CSD-affected trees, more frequently in Pera (Fig. 5I) than in Natal, Hamlin, and Valencia sweet orange (data not shown). Conspicuous necrotic areas were present throughout the NFP (Fig. 5D and E), and phloem elements were lignified in the old NFP (Fig. 5E: enlargement from zone III of Fig. 4B). In addition, medullar rays were curved (Fig. 5D). Finally, accumulation of starch grains was observed in the parenchyma cells of both phloem and cortex immediately below the bud union (Fig. 7D and E).

None of the pathological features described above were seen in the bud union bark of symptomless Pera sweet orange trees on Rangpur lime (Fig. 3A and B) or Cleopatra mandarin (data not shown) from the CSD-free Matão region. Among the symptomless Pera sweet orange trees on Rangpur lime from the CSD-affected Comendador Gomes region, one had normal bark (data not shown), but the bark from a second one (Fig. 3C and D) showed early anatomical symptoms: rather thick bark, accumulation of NFP, abnormal FP with chromatic cells and necrotic sieve tube areas (Fig. 5C), phloem cells smaller than normal cells, but still larger than phloem cells from symptomatic trees (Compare Fig. 5A to $\mathrm{C}$ ), indicating that this tree was probably affected, and that anatomical symptoms precede external ones as well as the yellow discoloration of Rangpur lime bark.

The pathological changes described above for bud union bark of CSD-affected sweet orange trees on Rangpur lime were very similar to those observed in the bud union bark of tristeza-affected sweet orange trees on sour orange (Fig. 4C and D). An excessive amount of NFP was seen not only in the sour orange bark (Fig. 4D), but also in the sweet orange bark (Fig. 4C). In the young FP, obliteration, collapse, and necrosis of sieve tubes and companion cells (Fig. 6I) occurred, and medullar rays were hyperplastic and/or hypertrophic (Fig. 6H). Chromatic cells were present in the sweet orange bark, but not in the sour orange bark (data not shown). Some of the hyperplastic rays in the sour orange bark below the bud union were lignified (Fig. 4D: lir), and in this case, when bark was removed, the lignified rays remained generally attached to the xylem, resulting in small corresponding pits on the cambial side of the removed piece of bark (inverse stem pitting or honeycombing) (Fig. 4D: pi). Occasionally, a few lignified rays were seen in the FP (Fig. 4D), but most frequently they were absent (Fig. 6H). Even though no such lignified rays were seen in the Rangpur lime bark from CSD-affected trees, a slight honeycombing could be observed with a magnifying lens on the cambial side of Rangpur lime bark from trees showing level 2 decline.

Bark anatomy at approach-graft union of inarched Rangpur lime seedlings. CSD-affected sweet orange trees inarched with Rangpur lime seedlings were from the CSD-affected regions of Comendador Gomes (Fig. 1: 5) and Colombia (Fig. 1: 12). Rangpur lime seedling bark was taken near the approach-graft union, cross sectioned, and examined by light microscopy (Fig. 6A to G).

The pathological anatomy described above for Rangpur lime bark at the bud union of CSD-affected trees was particularly evident in the bark of Rangpur lime seedlings inarched to the sweet orange scion of CSD-affected trees. The deepest alterations were seen when the bark of the seedling showed the characteristic yellow staining at sampling distance " $0 \mathrm{~cm}$ " from the approach-graft union (Fig. 6B, C, and $\mathrm{G})$, where the FP was very limited or practically absent (Fig. 6G). Anatomical symptoms were present even in the absence of yellow stain. For instance, in the case of the three seedlings inarched to one of the Hamlin sweet orange trees, one seedling (Fig. 2G, seedling 2) had yellow bark and severe anatomical symptoms (Fig. 6G). Seedling 1 (Fig. 2G) did not yet display the yellow stain, but showed nevertheless anatomical symptoms, the intensity of which decreased from sampling distance " $0 \mathrm{~cm}$ ", close to the graft union (Fig. 6D), to distances " $6 \mathrm{~cm}$ " (Fig. 6E) and "10 cm" (Fig. 6F). The amount of FP was normal at "10 cm" and most reduced at " $0 \mathrm{~cm}$ ". Similar results were obtained with seedling 3 (Fig. 2G), also without yellow stain yet (data not shown). No anatomical alterations were observed in the bark of Cleopatra mandarin seedlings inarched to CSDaffected trees (Fig. 6A).

Bark anatomy at bud union of Volkamer lemon rootstock and at ap- proach-graft union of inarched Volkamer lemon seedlings. The pathological anatomy of Volkamer lemon bark below the bud union of CSD-affected Valencia sweet orange trees on this rootstock (Fig. 8B) and at the approach graft union of Volkamer lemon seedlings inarched to CSD-affected Hamlin sweet orange trees on Rangpur lime (Fig. 8D) was similar to that observed in the case of Rangpur lime bark. In particular, the increase of NFP and the relative proportions of FP to NFP were quite similar (compare Fig. 8B to Fig. 4B for rootstock bark, and Fig. 8D to Fig. 6B and $\mathrm{D}$ to $\mathrm{G}$, for approach-graft bark). The Volkamer lemon bark at the bud union of CSD-affected trees was thicker than that from nonaffected trees (data not shown) because of the accumulation of NFP in the bark from affected trees (Fig. 8A and B). In contrast, the bark from the Volkamer lemon seedling inarched to the CDSaffected tree (Fig. 8D), and showing the characteristic yellow stain in the bark, was thinner than that from the seedling approach-grafted to the unaffected tree (Fig. $8 \mathrm{C})$ because the overall growth and increase in diameter of the latter seedling, unaffected by CSD, was higher than that of the affected seedling. However, the ratio of NFP to FP was higher in the affected bark than in the unaffected one (compare Fig. $8 \mathrm{C}$ to $\mathrm{D}$ ).

Inarching CSD-affected sweet orange trees on Rangpur lime. CSD-affected trees could be recovered by inarching them above their bud union lines with seedlings of Cleopatra mandarin or Swingle citrumelo. Trees on these rootstocks have never shown symptoms of CSD in the affected regions (Fig. 2B). However, when the seedling used for inarching was Rangpur lime, no recovery was obtained as the Rangpur lime bark near the approach-graft became affected by sieve tube collapse and necrosis, and showed the characteristic yellow discoloration, as described above. Also, within a period of 16 months (5 December 2001 to 4 April 2003), the average diameter of the inarched Rangpur lime seedlings increased from 6.7 to $17.1 \mathrm{~mm}$, i.e., by $10.4 \mathrm{~mm}$, while the diameters of inarched Swingle citrumelo and Cleopatra mandarin seedlings increased by 21.4 and $16.0 \mathrm{~mm}$, respectively.

CTV coat protein and dsRNA in CSDaffected and unaffected trees. CTV was detected by ELISA and dsRNA profiles in all trees tested, whether they were affected by CSD or not. The ELISA value in Rangpur lime bark was 0.478 for CSD-affected trees (average of 7 trees) and 0.617 for unaffected trees (average of 9 trees), whereas the ELISA value of sour orange rootstock bark of CTV-infected trees from Valencia, Spain, was only 0.005 (average of 12 trees). In contrast to rootstock bark, the ELISA values for sweet orange scion bark from CTV-affected trees in Spain and CSD-affected and unaffected trees in 

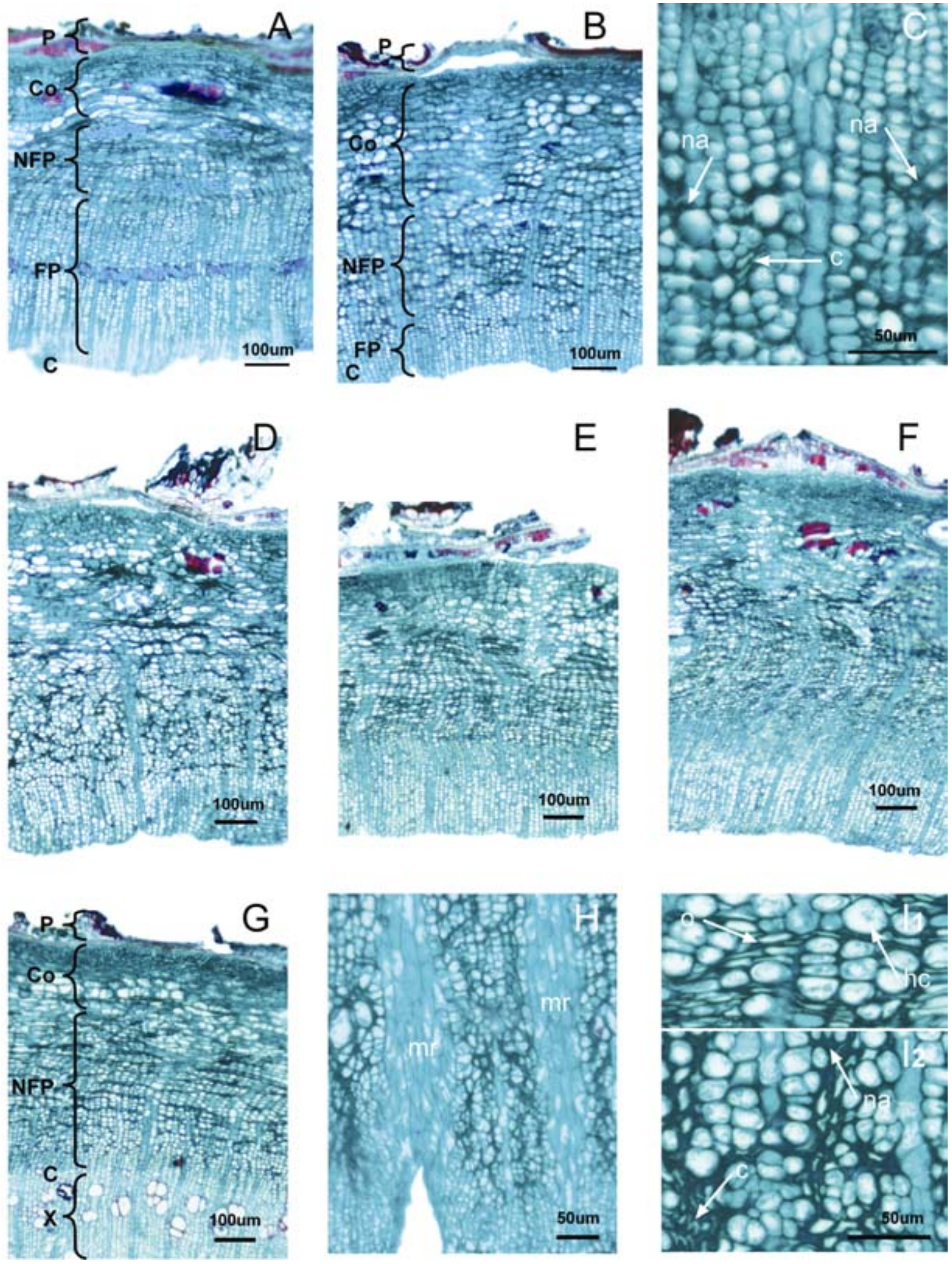

Fig. 6. Cross sections of bark from approach-grafted Rangpur lime and Cleopatra mandarin seedlings, and from sour orange bud union bark of tristeza affected tree. $\mathrm{C}=$ cambium; $\mathrm{Co}=$ cortex; $\mathrm{FP}=$ functioning phloem; NFP = nonfunctioning phloem; $\mathrm{P}=$ peridermis; $\mathrm{X}=$ xylem. $\mathbf{A}$, Cleopatra mandarin seedling approach-grafted (inarched) to a Citrus Sudden Death (CSD)-affected Hamlin sweet orange tree on Rangpur lime. Cross section of Cleopatra mandarin bark near approach-graft union (distance "0", corresponding to arrowhead of Figure 2G). Normal tissue characteristics. Important zone of FP. B, Rangpur lime approachgrafted to a CSD-affected Valencia sweet orange tree on Rangpur lime. Cross section of seedling bark near approach-graft union (distance "0" corresponding to arrowhead of Figure 2G). Bark sample showed yellow discoloration. Narrow zone of FP. Necrotic areas in FP (see also section C). C, Enlargement of FP of cross section B. na = necrotic areas; c = collapsed sieve tubes. D to F, Rangpur lime seedling approach-grafted to CSD-affected Hamlin sweet orange tree on Rangpur lime. Cross sections of seedling bark from distance " $0 \mathrm{~cm}$ " (D), " $6 \mathrm{~cm}$ " (E), and " $10 \mathrm{~cm}$ " (F). Yellow stain in none of the three bark samples, yet. Anatomical pathology of section $\mathbf{D}$ is similar to that of section $\mathbf{B}$ from bark sample with yellow stain. Smallest FP zone in section $\mathbf{D}$, closest to graft-union. $\mathbf{G}$, Rangpur lime seedling approach-grafted to CSD-affected Hamlin sweet orange tree on Rangpur lime. Cross section of seedling bark near graft union (distance "0 cm"). Bark was stained yellow. Practically no FP. One of few sections with xylem (X). H and I, Sour orange bud union bark from CTV-affected Navelate sweet orange tree from Picassent, Valencia, Spain. H, cross section of young FP near cambial zone, with necrotic areas (see also I) and hyperplastic medullar rays (mr). The $\Lambda$-shaped pit corresponds to a lignified medullar ray having remained attached to xylem (see Figure 4D). I, enlargement of young FP of section $\mathbf{H}$, with obliterated (o), collapsed (c) cells, necrotic areas (na), and hypertrophic parenchyma cell (hc). 
Brazil, were similar and reached 0.342 , 0.413 , and 0.513 , respectively. In fruit peduncles from both CSD-affected and unaffected trees, the ELISA values were close to 1.9. All trees tested in Brazil reacted positively with MCA13.

The dsRNA pattern and the SSCP pattern of the cDNA-CTV $p 20$ gene could not discriminate between trees with and without CSD, or trees from CSD-affected or unaffected regions.

Search for viruses and virus-like pathogens other than CTV. Negative results were obtained by indirect tissue print-ELISA with 41 monoclonal antibodies against the following viruses: BLRV, BMYV, BWYV, BYDV, BYV, CMV, PLRV, PSV, PVY, RNV, and TuYV. Potyvirus-specific antibodies also gave negative results. The CSD-affected trees examined for viruses other than CTV were also analyzed for the presence of viroids, including Citrus exocortis viroid (CEVd), and small circular RNAs, but not even traces of these molecules could be detected by sequential PAGE analysis followed by silver staining. However, viroids including CEVd were detected in samples of trees showing bark scaling on the Rangpur lime rootstock collected within an orchard severely affected by CSD.

\section{DISCUSSION}

Pathological anatomy of bud union bark from CSD-affected and tristezaaffected trees. Schneider was the first to describe the pathological anatomy of the sour orange rootstock bark at the bud union of tristeza-affected sweet orange trees (35). The sieve tubes in the young FP collapse, are obliterated, and become necrotic. A primary anatomical symptom is the presence of chromatic cells adjacent to sieve tubes (36). Sieve-tube necrosis in the young FP induces an over-activity of phloem production at the bud union, and the phloem cells that are produced are smaller than normal. The band of new phloem functions for some time before becoming necrotic and being pushed away from the cambium toward the cortex by a newly synthesized phloem band. This process repeats itself. The oldest necrotic bands invade the cortex, where crushing of the phloem elements ensues. An excessive amount of NFP accumulates, not only in the sour orange bark, but also in the sweet orange bark. As shown in this work, the pathological anatomy of Rangpur lime and Volkamer lemon bark, as well as sweet orange bark, in the vicinity of the bud union of CSD-affected sweet orange trees, is strikingly similar to that seen in the bark of the sour orange rootstock and the sweet orange scion in tristeza-affected trees. In the case of CSD, chromatic cells were observed, not only in the sweet orange bark above the bud union, but also in the Rangpur lime bark below the bud union; whereas in the case of tristeza, the
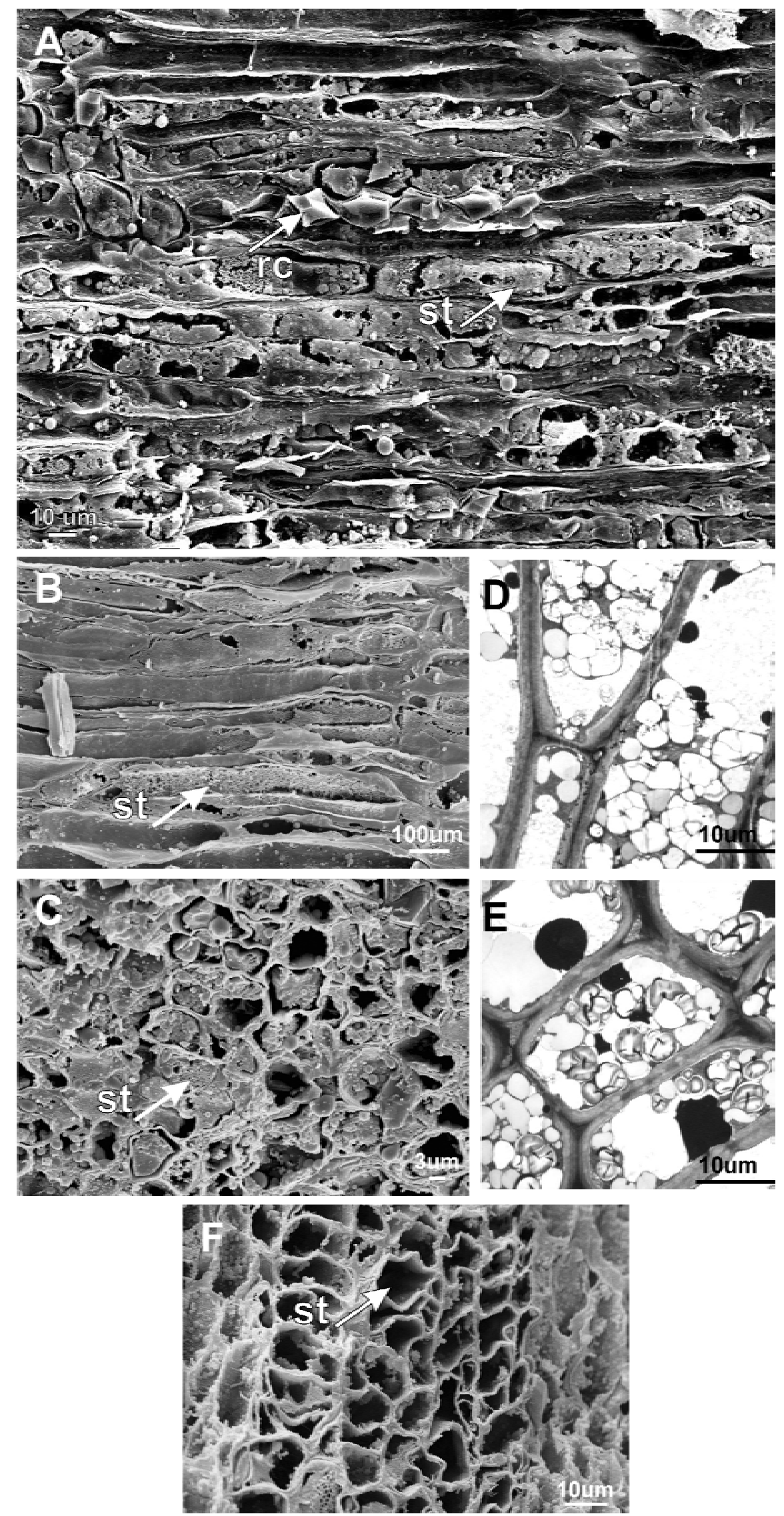

Fig. 7. Scanning (A to C, F) and transmission (D, E) electron micrographs of Rangpur lime bark near the bud union of an unaffected tree from Matão (F) and a Citrus Sudden Death (CSD)-affected sweet orange tree from Comendador Gomes (A to E). Longitudinal (A and B) and cross (C to F) sections. Arrows point at sieve tubes (st) empty (F) or occluded with amorphous material (A to C), and rhomboedric crystals (rc, A). Cortical (D) and phloem (E) parenchyma cells with accumulation of starch grains and dense material in the vacuole. 
(B)

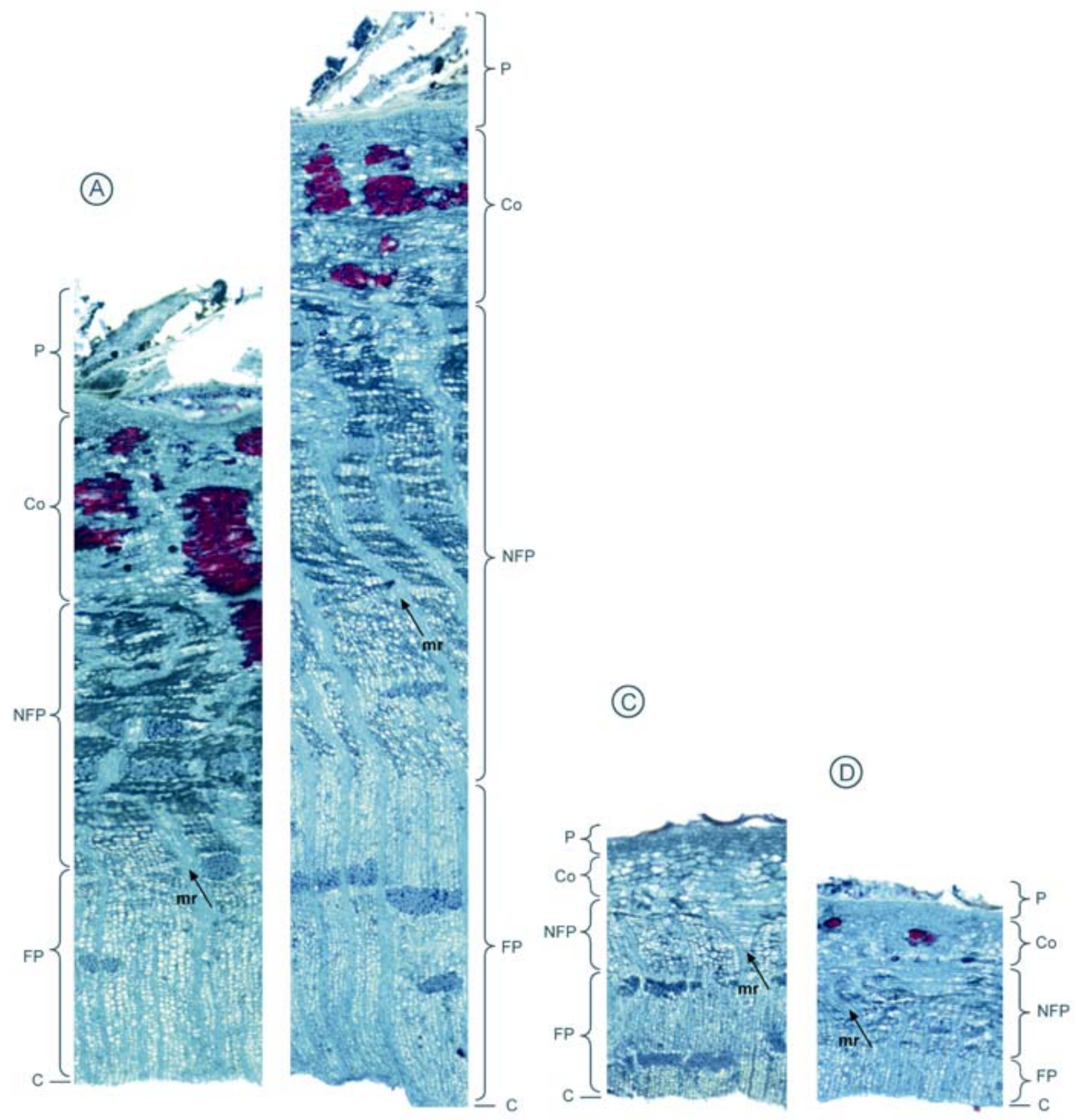

100 um

Fig. 8. Cross section of Volkamer lemon rootstock bark from bud union of unaffected (A) and Citrus Sudden Death (CSD)-affected (B) Valencia sweet orange trees on Volkamer lemon, and bark from Volkamer lemon seedlings inarched to unaffected (C) and CSD-affected (D) Hamlin sweet orange trees on Rangpur lime. $\mathrm{C}=$ cambium; $\mathrm{Co}=$ cortex; $\mathrm{FP}=$ functioning phloem; $\mathrm{mr}=$ medullar rays; $\mathrm{NFP}=$ nonfunctioning phloem; $\mathrm{P}=$ peridermis. $\mathbf{A}$, Normal tissue characteristics. Good equilibrium between FP and NFP. Collapse of old phloem tissue only. Straight medullar rays in FP and curved rays in NFP. B, Excessive amount of NFP, accounting for bark thickness. Cortex invaded by oldest NFP. C, Normal tissue characteristics. Good equilibrium between FP and NFP. D, Overproduction of NFP. 
chromatic cells have not been seen in the sour orange bark. It has been speculated that chromatic cells could be cells infected with CTV (36). If so, the fact that they were not seen in sour orange phloem could be related to the very low CTV accumulation observed in the sour orange rootstock bark, in comparison with the rather high content of CTV in Rangpur lime rootstock bark.

Young sweet orange trees on sour orange exposed to natural CTV infection may decline in just 6 months. In contrast, CSD-affected young sweet orange trees on Rangpur lime showed the first symptom of infection, i.e., the yellow stain in the Rangpur lime bark, only after 22 months in the field, and only a small proportion of such trees had yellow bark at that time. Delay in symptom expression in the case of CSD might be related to the fact that even in severely CSD-affected field trees, the Rangpur lime and the Volkamer lemon rootstock bark still have an appreciable amount of FP even though it has areas of necrotic and collapsed sieve tubes; while in the case of tristeza, the FP of the sour orange bark is significantly more reduced. However, the Rangpur lime seedlings inarched to CSD-affected sweet orange trees showed particularly evident anatomical alterations, and the FP in the seedling bark was very limited or practically absent, especially when the seedling bark had the characteristic yellow discoloration.

It is believed that sieve-tube necrosis and phloem degradation in tristeza-affected trees prevent the movement of photoassimilates to the root system. Subsequent starvation and decay of the roots (24) explain the decline associated with the disease, the symptoms of which are therefore nonspecific. Canopy decline and root decay of CSD-affected sweet orange trees are indistinguishable from those caused by CTV on sweet orange trees grafted on sour orange, and both occur most likely through the same mechanism. However, in tristeza, starch accumulates above the bud union, while in CSD, accumulation of starch grains has been observed immediately below the bud union in the parenchyma cells of both phloem and cortex.

Sweet orange trees on Volkamer lemon rootstock with levels 1 and 2 decline symptoms suggesting CSD were only seen in June 2003 affecting 3- and 6-year-old trees. For the following reasons, it is probably the same disease, namely CSD, that affects sweet orange trees on both Rangpur lime and Volkamer lemon rootstocks: (i) External symptoms are similar. Leaves become pale green and lose their shininess, and trees show defoliation and root rot. Affected trees show below the bud union the characteristic yellow stain in the bark. (ii) Volkamer lemon seedlings inarched above the bud union line to CSDaffected sweet orange trees on Rangpur lime develop the yellow bark stain at the approach-graft union within 18 months. (iii) The pathological anatomy of bud union bark of sweet orange trees on Rangpur lime and on Volkamer lemon is very similar.

In conclusion, the pathological anatomies of bud union bark from tristezaaffected trees on sour orange and CSDaffected trees on Rangpur lime or Volkamer lemon are remarkably similar in spite of some differences, and can account for both declines.

CSD, a bud union disease. Although CTV causes decline of sweet orange trees grafted on sour orange, neither sweet orange nor sour orange declines when grown on their own roots. For this reason, tristeza is a bud union disease. In the CSD-affected region, sweet orange trees are not grown on their own roots (seedling trees), and therefore it was not possible to assess their tolerance to CSD. However, it is likely that sweet orange is tolerant to the CSD agent for the following reasons: (i) The CSD pathogen could be graft-transmitted under insect-proof conditions by sweet orange buds and bud wood sticks taken from field trees grafted on Cleopatra mandarin rootstock (42). These trees were symptomless even though they were infected as shown by the positive results of the grafttransmission experiment. (ii) Symptomatic CSD-affected sweet orange trees on Rangpur lime recover and become symptomless when inarched with Cleopatra mandarin or Swingle citrumelo seedlings. It can thus be assumed that sweet orange is tolerant to CSD. Several observations indicate that Rangpur lime is sensitive to the CSD agent. In this context, it should be remembered that Rangpur lime is also sensitive to stem pitting strains of CTV (28), and that sour orange seedlings are sensitive to CTV isolates causing seedling yellows (12). However, in spite of the sensitivity of Rangpur lime to the CSD agent, and for the following reasons, CSD is, like tristeza, a bud union disease: (i) Trees on certain rootstocks (Cleopatra and Sunki mandarins, Swingle citrumelo) have never shown symptoms of CSD and are considered tolerant to its causal agent. In the case of Cleopatra mandarin, this hypothesis is supported by the fact that the bud union bark of trees on this rootstock within the CSD-affected region shows none of the anatomical symptoms characteristic of trees on Rangpur lime. (ii) CSD-affected trees could be recovered by inarching them above their bud union lines with the rootstock seedlings giving CSD-tolerant combinations with sweet orange. However, when the seedlings used for inarching were Rangpur lime, no recovery was obtained as the Rangpur lime bark near the approachgraft showed sieve tube collapse and necrosis, and the characteristic yellow discoloration. The recognition that CSD was a bud union disease prompted the use of inarching as a measure to save young trees on Rangpur lime or Volkamer lemon, sen- sitive to CSD. Today, over 1.5 million young sweet orange trees on Rangpur lime are already inarched with Swingle citrumelo and/or Cleopatra mandarin seedlings.

Etiology of CSD. At this time, the cause of CSD is not known. However, a biotic agent must be involved since the disease could be transmitted by graft-inoculation under insect-proof conditions (42). Grafttransmitted agents are viroids, viruses, or endogenous (phloem- and xylemrestricted) bacteria. Search for endogenous, as well as exogenous, bacteria has produced negative results (5). As reported here, no viroids were detected in CSDaffected trees. The following observations suggest that a new CTV strain, able to induce decline of trees on Rangpur lime and Volkamer lemon, might be involved in CSD:

(i) As reported earlier (5), epidemiological analyses revealed remarkable similarities between the spatial patterns of CSDsymptomatic trees and CTV-infected trees in situations where $T$. citricida is the main vector. This similarity suggests that $T$. citricida, which is ubiquitous in the Brazilian citrus industry, could also be the vector of the CSD agent. If so, the new CTV should be widely spread by this aphid, and infect not only symptomatic trees on Rangpur lime and Volkamer lemon, but also symptomless trees on other rootstocks such as Cleopatra mandarin. This is precisely what has been found, since buds and bud sticks from such trees were able to graft-transmit the disease (42).

(ii) CTV has been detected by ELISA and dsRNA profiles in all trees tested, whether they were affected by CSD or not. This result is not surprising, as CTV is present in virtually all citrus trees in Brazil, a country where about 70 million Pera sweet orange trees are cross-protected with a mild, Brazilian CTV isolate (11), and where $T$. citricida, the most efficient CTV vector, is prevalent.

(iii) As shown here, the pathological anatomy of Rangpur lime and Volkamer lemon bark, as well as sweet orange bark, in the vicinity of the bud union of CSDaffected sweet orange trees is strikingly similar to that seen in the bark of the sour orange rootstock and the sweet orange scion in tristeza-affected sweet orange trees.

(iv) Both CSD and tristeza decline are bud union diseases and can be controlled by inarching with tolerant rootstocks (Cleopatra and Sunki mandarins, Swingle citrumelo).

The "new CTV" hypothesis can explain all known features of CSD. However, the involvement in CSD of a virus other than CTV cannot be excluded, and efforts to detect such a virus(es) have been ongoing. As reported here, a search for a number of viruses using specific antibodies gave negative results. Negative ELISA reactions were also obtained with antibodies against 
the luteoviruses PLRV and Sugar cane yellow leaf virus, and Apple stem grooving virus, a capillovirus closely related to Citrus tatter leaf virus (J. A. M. Rezende and Q. S. Novaes, unpublished data). Murilo Zerbini (unpublished data) failed to detect geminiviruses in CSD-affected trees from an orchard in Comendador Gomes (Southern Minas Gerais State) in which Sida rhombifolia, a plant known as a notorious host of geminiviruses and a good source of inoculum, was prevalent and found to be infected by a Bemisia tabaci-transmitted begomovirus.

Recently, RNA sequences with homology to a viral RNA from the family $T y$ moviridae have been detected in CSDaffected trees, but not in trees from the unaffected regions (Reinach F., Alellyx, Applied Genomics, public conference on CSD, 14 October 2003). However, none of the known Tymoviridae viruses have aphid vectors. Yet the epidemiological studies on CSD seem to suggest that spread of the disease is by an insect vector such as $T$. citricida, the brown citrus aphid. It cannot be excluded that the new virus would be transmitted by such an insect. There is, however, another possibility if it is proved that the new virus is involved in CSD. CTV is known to be present in all citrus trees in the State of São Paulo and could be required for the new virus to be transmitted by $T$. citricida or a similar CTV aphid vector. For instance, potexviruses such as Potato virus $X$ are not aphid transmissible. Yet Potato aucuba mosaic virus (PAMV), also a potexvirus, can be transmitted by aphids from plants co-infected with a potyvirus, Potato virus A or Potato virus $Y$, but not from plants infected by PAMV alone (21). The mechanism of this helpervirus-mediated aphid transmission of PAMV has been elucidated (6).

Effects of CSD on the citrus industry. In the Paulista citrus belt, as much as $85 \%$ of sweet orange trees are grafted on Rangpur lime, because with this rootstock, trees can be grown without irrigation. Volkamer lemon is also drought resistant and could have been a substitute for Rangpur lime, but trees on that rootstock have now been found to be affected by CSD. Trees on Cleopatra and Sunki mandarins and Swingle citrumelo are tolerant to CSD, but they would require irrigation in dry regions. Seedlings of Cleopatra mandarin and Swingle citrumelo have already been used to inarch more than one million young CSD-affected trees. Even though this measure appears to be successful, CSD remains a serious problem, whatever the causal agent is, especially if the disease keeps spreading in northern regions and new foci appear in southern unaffected regions, as seems to be occurring. Eventually the Paulista citrus industry may be forced to consider irrigation of citrus plantings, a secondary but important consequence of CSD.
LITERATURE CITED

1. Albiach-Martí, M. R., Mawassi, M., Gowda, S., Satyanarayana, T., Hilf, M. E., Shanker, S., Almira, E. C., Vives, M. C., López, C., Guerri, J., Flores, R., Moreno, P., Garnsey, S. M., and Dawson, W. O. 2000. Sequences of citrus tristeza virus separated in time and space are essentially identical. J. Virol. 74:6856-6865.

2. Ayllón, M. A., López, C., Navas-Castillo, J., Mawassi, M., Dawson, W. O., Guerri, J., Flores, R., and Moreno, P. 1999. New defective RNAs from citrus tristeza virus: Evidence for a replicase-driven template switching mechanism in their generation. J. Gen. Virol. 80:817821.

3. Ayllón, M. A., Rubio, L., Moya, A., Guerri, J., and Moreno, P. 1999. The haplotype distribution of two genes of citrus tristeza virus is altered after host change or aphid transmission. Virology 255:32-39.

4. Bar-Joseph, M., and Lee, R. F. 1989. Citrus tristeza virus. A.A.B. Descriptions of Plant Viruses No. 353.

5. Bassanezi, R. B., Bergamin Filho, A., Amorim, L., Gimenes-Fernandes, N., Gottwald, T. R., and Bové, J. M. 2003. Spatial and temporal analyses of citrus sudden death as a tool to generate hypotheses concerning its etiology. Phytopathology 93:502-512.

6. Baulcombe, D. C., Lloyd, J., Manoussopoulos, I. N., Roberts, I. M., and Harrison, B. D. 1993. Signal for potyvirus dependent aphid transmission of Potato aucuba mosaic virus and the effect of its transfer to Potato virus X. J. Gen. Virol. 74:1245-1253.

7. Bové, J. M., Garnier, M., Gimenes-Fernandes, N., Bassanezi, R. B., Yamamoto, P. T., and Ayres, A. J. 2002. Sudden death disease (Morte Súbita Doença) of sweet orange trees on Rangpur lime: A hypothesis. Report to Fundecitrus, February 2002

8. Cambra, M., Camarasa, E., Gorris, M. T., Garnsey, S. M., and Carbonell, E. 1991. Comparison of different immunosorbent assays for Citrus tristeza virus (CTV) using CTV-specific monoclonal and polyclonal antibodies. Pages 38-45 in: Proc. Conf. IOCV, 11th. R. H. Brlansky, R. F. Lee, and L. W. Timmer, eds. IOCV, Riverside, CA

9. Cambra, M., Garnsey, S. M., Permar, T. A., Henderson, C. T., Gumpf, D., and Vela, C. 1990. Detection of citrus tristeza virus (CTV) with a mixture of monoclonal antibodies. (Abstr.) Phytopathology 80:1034.

10. Cambra, M., Gorris, M. T., Román, M. P., Terrada, E., Camarasa, E., Olmos, A., and Colomer, M. 2000. Routine detection of citrus tristeza virus by direct immunoprinting-ELISA method using specific monoclonal and recombinant antibodies. Pages 34-41 in: Proc. Conf. IOCV, 14th. da J. V. Graça, R. F. Lee, and R. K. Yokomi, eds. IOCV, Riverside, CA.

11. Costa, A. S., and Müller, G. W. 1980. Tristeza control by cross protection: A U.S.-Brazil cooperative success. Plant Dis. 64:538-541.

12. Fraser, L. 1952. Seedling yellows, an unreported virus disease of citrus. Agric. Gaz. N.S.W. 63:125-131.

13. Garnsey, S. M., Permar, T. A., Cambra, M., and Henderson, C. T. 1993. Direct tissue blot immunoassay (DTBIA) for detection of citrus tristeza virus (CTV). Pages 39-50 in: Proc. Conf. IOCV, 12th. P. Moreno, J. V. da Graça, and L. W. Timmer, eds. IOCV, Riverside, CA.

14. Gimenes-Fernandes, N., and Bassanezi, R. B. 2001. Doença de causa desconhecida afeta pomares citricos no norte de São Paulo e Sul do Triângulo Mineiro. Summa Phytopathol. 27:93.

15. Hilf, M. E., Karasev, A. V., Albiach-Marti, M. R., Dawson, W. O., and Garnsey, S. M. 1999. Two paths of sequence divergence in the citrus tristeza virus complex. Phytopathology 89:336-342.
16. Hughes, W. A., and Lister, C. A. 1949. Lime disease in the Gold Coast. Nature 164:880.

17. Igloi, G. L. 1983. Silver staining for the detection of nanogram amounts of tRNA following two-dimensional electrophoresis. Anal. Biochem. 134:184-188.

18. Jensen, W. 1962. Botanical Histochemistry: Principles and Practice. Freeman \& Co., San Francisco.

19. Johansen, D. A. 1940. Plant Microtechnique. Microchemical Methods. Chapter XV. McGraw-Hill Book Co., New York.

20. Karasev, A. V., Boyko, V. P., Gowda, S., Nikolaeva, O. V., Hilf, M. E., Koonin, E. V., Niblett, C. L., Cline, K., Gumpf, D. J., Lee, R. F., Garnsey, S. M., Lewandowsky, D. J., and Dawson, W. O. 1995. Complete sequence of the citrus tristeza virus RNA genome. Virology 208:511-520.

21. Kassanis, B. 1961. The transmission of aucuba mosaic virus by aphids from plants also infected by potato viruses A or Y. Virology 13:93-97.

22. Mawassi, M., Mietkiewska, E., Gofman, R. Yang, G., and Bar-Joseph, M. 1996. Unusual sequence relationships between two isolates of citrus tristeza virus. J. Gen. Virol. 77:23592364.

23. Meneghini, M. 1946. Sobre a natureza e transmissibilidade do doencia "tristeza" dos citros. O Biológico 12:285-287.

24. Moreira, S. 1942. Observações sobre "tristeza" dos citros ou "podridão das radicelas". O Biológico 8:269-272.

25. Moreno, P., Guerri, J., Ballester-Olmos, J. F., and Martínez, M. E. 1991. Segregation of citrus tristeza virus strains evidenced by double stranded RNA (dsRNA) analysis. Pages 113 120 in: Proc. Conf. IOCV, 11th. R. H. Brlansky, R. F. Lee, L. W. Timmer, eds. IOCV, Riverside, CA.

26. Moreno, P., Guerri, J., and Muñoz, N. 1990. Identification of Spanish strains of citrus tristeza virus by analysis of double-stranded RNAs. Phytopathology 80:477-482.

27. Müller, G. W., de Negri, J. D., AguilarVildoso, C. I., Mattos Junior, D., Pompeu Junior, J., Teofilo Sobrinho, J., Carvalho, S. A., Girotto, L. F., and Machado, M. A. 2002. Morte súbita dos citros: uma nova doença na citricultura brasileira (Citrus sudden death: A new disease in the Brazilian citriculture). Laranja 23:371-386.

28. Müller, G. W., Rodriguez, O., and Costa, A. S. 1968. A tristeza virus complex severe to sweet orange varieties. Pages 64-71 in: Proc. Conf IOCV, 4th. J. F. L. Childs, ed. University of Florida Press, Gainesville.

29. Oberholzer, P. C. J., Mathews, I., and Stiemie, S. F. 1949. The decline of grapefruit trees in South Africa: A preliminary report on so-called "stem pitting”. So. Afr. Dep. Agric. Sci. Bull. 297.

30. Permar, T. A., Garnsey, S. M., Gumpf, D. J., and Lee, R. F. 1990. A monoclonal antibody that discriminates strains of citrus tristeza virus. Phytopathology 80:224-228.

31. Richter, J., Rabenstein, F., Proll, E., and Vetten, H. J. 1995. Use of cross-reactive antibodies to detect members of the Potyviridae. J. Phytopathol. 143:459-464.

32. Rivera-Bustamante, R. F., Gin, R., and Semancik, J. S. 1986. Enhanced resolution of circula and linear molecular forms of viroid and viroid-like RNA by electrophoresis in a discontinuous-pH system. Anal. Biochem. 156:91-95.

33. Rocha-Peña, M. A., Lee, R. F., Lastra, R., Niblett, C. L., Ochoa-Corona, F. M., Garnsey, S. M., and Yokomi, R. K. 1995. Citrus tristeza virus and its aphid vector Toxoptera citricida: Threats to citrus production in the Caribbean and Central and North America. Plant Dis 79:437-445.

34. Rubio, L., Guerri, J., and Moreno, P. 2000. Characterization of Citrus tristeza virus iso- 
lates by single strand conformation polymorphism analysis of DNA complementary to their RNA population. Pages 12-17 in: Proc. Conf. IOCV, 14th. J. V. da Graça, R. F. Lee, and R. K. Yokomi, eds. IOCV, Riverside, CA.

35. Schneider, H. 1954. Anatomy of bark of bud union, trunk, and roots of quick-declineaffected sweet orange trees on sour orange rootstock. Hilgardia 22:567-581.

36. Schneider, H. 1959. The anatomy of tristezavirus-infected citrus. Pages 73-84 in: Citrus Virus Diseases. J. M. Wallace, ed. University of California Division Agricultural Sciences, Berkeley.

37. Semancik, J. S., Morris, T. J., Weathers, L. G., Rordorf, L. G., and Kearns, D. R. 1975. Physical properties of a minimal infectious RNA (viroid) associated with the exocortis disease.
Virology 63:160-167.

38. Suastika, G., Natsuaki, T., Terui, H., Kano, T., Ieki, H., and Okuda, S. 2001. Nucleotide sequence of Citrus tristeza virus seedling yellows isolate. J. Gen. Plant Pathol. 67:73-77.

39. Van Regenmortel, M. H. V., Fauquet, C. M., Bishop, D. H. L., Carstens, E. B., Estes, M. K., Lemon, S. M., Maniloff, J., Mayo, M. A., McGeoch, D. J., Pringle, C. R., and Wickner, R. B. 2000. Virus Taxonomy. Seventh Report of the International Committee on Taxonomy of Viruses. Academic Press, San Diego, CA.

40. Vela, C., Cambra, M., Cortés, E., Moreno, P. Miguet, J. G., Pérez de San Román, C., and Sanz, A. 1986. Production and characterization of monoclonal antibodies specific for citrus tristeza virus and their use for diagnosis. J. Gen. Virol. 67:91-96.
41. Vives, M. C., Rubio, L., López, C., NavasCastillo, J., Albiach-Martí, M. R., Dawson, W. O., Guerri, J., Flores, R., and Moreno, P. 1999. The complete genome sequence of the major component of a mild Citrus tristeza virus isolate. J. Gen. Virol. 80:811-816.

42. Yamamoto, P. T., de Jesus Junior, W. C., Bassanezi, R. B., Sanches, A. L., Ayres, A. J., Gi menes-Fernandes, N., and Bové, J. M. 2003. Transmission of the agent inducing symptoms of citrus sudden death by graft-inoculation under insect-proof conditions. (Abstr.) Fitopatol. Bras. (Suppl.) 28:S265

43. Yang, Z. N., Mathews, D. H., Dodds, J. A., and Mirkov, T. E. 1999. Molecular characterization of an isolate of Citrus tristeza virus that causes severe symptoms in sweet orange. Virus Genes 19:131-142. 